\title{
JAUNŲJŲ KREPŠININKIŲ FIZINIŲ KRŪVIŲ INTENSYVUMO PER PRATYBAS IR RUNGTYNES ADEKVATUMO TYRIMAS
}

\author{
Rasa Kreivytè, Šarūnè Valinskaitė \\ Lietuvos kūno kultūros akademija, Kaunas, Lietuva
}

\begin{abstract}
Rasa Kreivytè. Edukologijos mokslų doktorantè. Lietuvos kūno kultūros akademijos Sportinių žaidimų katedros asistentė. Mokslinių tyrimų
\end{abstract} kryptis — jaunujų krepšininkių sportinio rengimo ir varžybinès veiklos tyrimai.

\section{SANTRAUKA}

Jau devintame XX a. dešimtmetyje buvo prieita prie nuomonès, kad ŠSD yra objektyvus ir informatyvus žaidejju reagavimo ífizinius krūvius, ju parengtumo rodiklis. Krepšinio rungtyniu, pratybu eiga nèra pastovi kintant žaidimo intensyvumui, rungtyniu metu žaidejjui metant baudos metimus, per minutès pertraukèlę kinta ir širdies susitraukimu dažnio rodiklis ( $\breve{S} S D, k$. / min). Taigi vidutinis ŠSD kaitos rodiklis, kintant žaidimo intensyvumui, sukuria banguotas duomenu sekas.

Norint pasiekti optimalius treniravimo rezultatus svarbu žinoti tinkamiausius, vyraujančius pratybu ir rungtyniu fizinius krūvius, kurie atitiktu krepšininku adaptacijos galimybes, sportinio rengimo tikslus ir uždavinius.

Tyrimo tikslas — ¿vertinti fizinio krūvio intensyvuma ir jo tapatuma per pratybas bei rungtynes.

Tyrimo uždaviniai: 1) nustatyti fiziniu krūviu per pratybas ir rungtynes intensyvuma; 2) ivertinti pratybu ir rungtyniu fiziniu krūviu intensyvumo sqlygini atitikimo laipsní; 3) atskleisti 14-15 m. krepšininkiu reagavimo i specifinius fizinius krūvius ypatumus.

Tirtu krepšininkiu $(n=18)$ ¿žaidèju vyraujantis fizinio krūvio intensyvumo rodiklis (ŠSD) per pratybas buvo

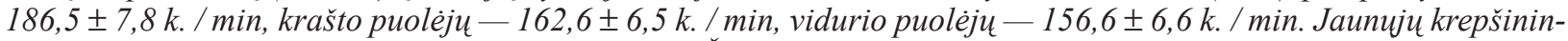

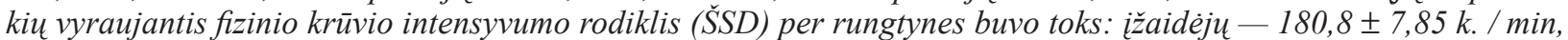

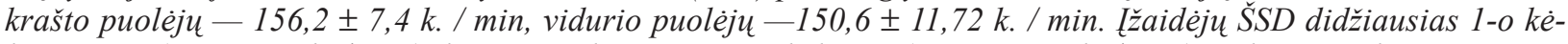
linio metu $(183,7 \pm 3 \mathrm{k} . / \mathrm{min})$, krašto puolèju — 2-ame kèlinyje (156,9 \pm 6,4 k. / min), vidurio puoleju - 3-iame $(153,5 \pm 5,5 \mathrm{k} . / \mathrm{min})$.

Tirtu jaunuju krepšininkiu (ž̌aidèju, krašto ir vidurio puolejju) fiziniu krūviu intensyvumas per pratybas ir rungtynes atitiko beveik didžiausio intensyvumo krūvio ribas. Ivairias funkcijas atliekančiu jaunuju krepšininkiu organizmas skirtingai reaguoja i Ł̇vairaus intensyvumo fizinius krūvius: jžaidèju ŠSD atliekant fizinius krūvius yra didesnis, lyginant su vidurio ir krašto puolèjomis. Vidurio puolejos i fizini krūvỉ reaguoja silpniausiai.

Raktažodžiai: fizinis krūvis, krūvio intensyvumas, širdies susitraukimu dažnis.

\section{IVADAS}

$\mathrm{V}$ iena veiksmingo sportinio jaunujų krepšininkių rengimo sąlygų yra realių krepšinio žaidimo veiksmų, situacijų perkèlimas $i$ pratybas — situacijų transpozicija. Transpozicijos kokybę nusako realių situacijų, kurios kyla žaidžiant, rungtyniaujant, ir situacijų, perkeltų i pratybas, atitikimo laipsnis — objektyvusis tų situacijų tapatumas (Avakumovič, 2000; Buceta, 2000; Stonkus, 2003).
Svarbiu tokio tapatumo požymiu yra fizinių krūvių intensyvumo per pratybas ir rungtynes adekvatumas (Buceta, 2000; Balčiūnas, 2005), nes optimalūs pratybų ir varžybų krūviai yra pagrindinis treniravimo veiksnys. To veiksnio itakos rezultatas — struktūriniai, fiziologiniai ir psichiniai krepšininko organizmo pokyčiai — prisitaikymas (Keen, 1995; Вompa, 1999; Созанский, Полищук, 2003; Balčiūnas, 2005). 
Norint pasiekti optimalius treniravimo pokyčius svarbu žinoti tinkamiausius, vyraujančius pratybų ir rungtynių fizinius krūvius, kurie atitiktu krepšininkų adaptacines galimybes, sportinio rengimo tikslus ir uždavinius (Milanovič et al., 2002; Созанский, Полищук, 2003; Petridis et al., 2004; Balčiūnas, 2005 ir kt.).

Antra vertus, reiketų atsižvelgti i tai, kad:

- nuo 12-ų gyvenimo metų išryškèja mergaičiu ir berniukų vystymosi, brandos skirtumai;

- mergaitès bręsta 2-3 m. greičiau;

- mergaičiu širdies galingumas po lytinio brendimo mažesnis negu vaikinų, todèl jų ŠSD didesnis;

- lytinio brendimo metu dar labiau išryškejja mergaičiu ir berniuku greitumo, vikrumo, jègos skirtumai, todèl būtina, kad jaunujų krepšininku krūvio intensyvumas, pobūdis atitiktu jų fizines galias ir psichikos ypatumus. Ypač tai svarbu sudètingu mergaičių brandos (14-15 m.) amžiaus tarpsniu (Crespo, Miley, 1998).

Pasigendama paauglių krepšininkių (14$15 \mathrm{~m}$.) pratybų ir rungtynių fizinių krūvių intensyvumo, jo tapatumo, jaunujų žaidèjų organizmo reagavimo i specifinius fizinius krūvius tyrimų.

Aktualu atsakyti i šiuos probleminius klausimus:

1. Kokie yra vyraujantys mergaičių krepšininkiu rungtynių ir pratybų fizinių krūvių intensyvumo rodikliai ir kokios jų tapatumo tendencijos?
2. Kaip $14-15$ m. krepšininkių organizmas reaguoja į specifinius fizinius krūvius?

Tyrimo objektas: fizinių krūvių intensyvumas ir jo tapatumas per jaunujų krepšininkiu pratybas ir rungtynes.

Tyrimo tikslas: ivertinti fizinio krūvio intensyvumą ir jo tapatumą per pratybas ir rungtynes.

\section{Tyrimo uždaviniai:}

1. Nustatyti fizinių krūviu per pratybas ir rungtynes intensyvumą.

2. Ivertinti pratybų ir rungtynių fizinių krūvių intensyvumo sąlygišką atitikimo laipsni.

3. Atskleisti $14-15 \mathrm{~m}$. krepšininkių reagavimo i specifinius fizinius krūvius ypatumus.

\section{TYRIMO ORGANIZAVIMAS IR METODIKA}

\section{Tyrimo metodai:}

1. Pedagoginis stebejjimas.

2. Pulsometrija.

3. Statistinè analizè.

Pedagoginis stebėjimas. Tyrimo metu buvo stebimos pratybos $(\mathrm{n}=12)$ :

- grupinių technikos veiksmų mokymo ir tobulinimo $(n=6)$,

- žaidimo $(3 \times 3,4 \times 4,5 \times 5)(\mathrm{n}=6)$.

Specialiame protokole buvo registruojama pratybų (pratimų atlikimo laikas, pratimų pobūdis, poilsio intervalai, atskirų žaidejų amplua ŠSD) ir

\begin{tabular}{|c|c|c|c|c|}
\hline \multirow{4}{*}{$\begin{array}{l}\text { Lentelè. Jaunųjų krepši- } \\
\text { ninkių ŠSD rodikliai per } \\
\text { pratybas (Stonkus, 2003) }\end{array}$} & \multirow{2}{*}{\multicolumn{2}{|c|}{ Krūvio pobūdis }} & \multirow{3}{*}{$\begin{array}{c}\begin{array}{c}\text { Pratimo } \\
\text { trukmè, min }\end{array} \\
5-7\end{array}$} & \multirow{3}{*}{$\begin{array}{c}\text { ŠSD, k. / min } \\
110-120\end{array}$} \\
\hline & & & & \\
\hline & \multirow{2}{*}{$\begin{array}{l}\text { Mažo } \\
\text { intensyvumo }\end{array}$} & Baudos metimai & & \\
\hline & & Metimai i krepši poromis be gynèjų & $8-12$ & $120-130$ \\
\hline & \multirow{5}{*}{$\begin{array}{l}\text { Vidutinio } \\
\text { intensyvumo }\end{array}$} & $2 \times 2 ; 3 \times 3$ i vieną krepši & $6-8$ & $150-160$ \\
\hline & & $5 \times 5$ prie vieno krepšio & $10-15$ & $150-160$ \\
\hline & & Perdavimai poromis & $4-5$ & $140-150$ \\
\hline & & Prasiveržimas varant kamuoli ir metimas i krepši & $5-7$ & $140-150$ \\
\hline & & $\begin{array}{l}\text { Z̈aidimas nenaudojant aktyvios gynybos ir greitojo } \\
\text { puolimo }\end{array}$ & $20-25$ & $150-160$ \\
\hline & \multirow{5}{*}{$\begin{array}{l}\text { Didelio } \\
\text { intensyvumo }\end{array}$} & $1 \times 1$ pusèje aikštès & $4-6$ & $160-180$ \\
\hline & & $3 \times 3$ visoje aikštèje & $7-9$ & $160-180$ \\
\hline & & $5 \times 5$ visoje aikštèje & $10-12$ & $160-180$ \\
\hline & & $2 \times 2$ visoje aikštèje & $9-10$ & $160-180$ \\
\hline & & $3 \times 2$ per aikštę & $6-8$ & $160-180$ \\
\hline & \multirow{5}{*}{$\begin{array}{l}\text { Didžiausio } \\
\text { intensyvumo }\end{array}$} & $1 \times 2$ visoje aikštèje & $8-10$ & $160-180$ \\
\hline & & Žaidimas aktyviai dengiant ir greitai puolant & $30-35$ & $170-190$ \\
\hline & & $\begin{array}{l}1 \times 1 \text { visoje aikštèje, prasiveržimas ir metimas i } \\
\text { krepši }\end{array}$ & $8-9$ & $160-180$ \\
\hline & & $\begin{array}{l}\text { Perdavimai poromis per aikštę pirmyn ir atgal (be } \\
\text { gynejjų) }\end{array}$ & $8-12$ & $\begin{array}{c}\text { Individualus } \\
\text { didžiausias }\end{array}$ \\
\hline & & $2 \times 3$ visoje aikštèje & $9-10$ & $\begin{array}{c}\text { Individualus } \\
\text { didžiausias }\end{array}$ \\
\hline
\end{tabular}


rungtynių (atskirų žaidèjų amplua ŠSD prieš rungtynes, pramankštos, atskirų kèlinių metu, pasibaigus rungtynèms, praejjus 1 min po rungtynių) eiga.

Tyrimo esmè: pratybų fizinius krūvius priartinti prie rungtynių fizinių krūvių, rungtynių situacijas perkeliant i pratybas.

Remiantis S. Stonkaus (2003) pateiktais duomenimis, kaip žaidejjai reaguoja i̇ fizinius krūvius per krepšinio pratybas, kokia žaidejjų reakcija i juos, širdies susitraukimų dažnis (ŠSD), buvo sudarytas jaunujų krepšininkių pratybų planas pagal veiklos pobūdi (mažo, vidutinio, didelio ir didžiausio intensyvumo) (žr. lent.).

Pulsometrija. Reagavimas ị tą patị fizinị krūvị (ypač greitumo, greitumo jègos) yra individualus ir priklauso nuo amžiaus, parengtumo, funkcinès sistemos būsenos. Todèl veiksmingam jaunujuc krepšininkų rengimui labai svarbūs reagavimo i pratybų ir varžybų krūvius rodikliai - ŠSD per vieną minutę (Buceta, 2000).

ŠSD buvo registruojamas pulsometru ir chronometru. Žaidejui prieš pratybas ar rungtynes užsidejus pulsometrą, buvo nuspaudžiamas chronometras. Chronometras sustabdomas tuo metu, kai žaidèja nusiimdavo pulsometrą. Visa užfiksuota informacija pratybu ir rungtynių metu buvo ikeliama i kompiuteri, naudojant „Polar Precision Performance" programa.

Pulsometrais „Polar Team System“ buvo registruojama jaunujų krepšininkių širdies susitraukimų (ŠSD) dažnis per krepšinio pratybas ir rungtynes 5 sekundžiu intervalu.

ŠSD analizuojamas tik per rungtynes, kurių metu krepšininkès žaidè ne mažiau kaip 30 min gryno žaidimo laiko.

Tyrimo organizavimas. Tyrimas truko vieną mènesi (2008 09 20-2008 10 22). Buvo vykdomos ketverios pratybos per savaitę, iš viso 12 $(\mathrm{n}=12)$ : žaidimo pratybų $(3 \times 3,4 \times 4,5 \times 5)$ $(n=6)$, grupiniu technikos veiksmu mokymo ir tobulinimo pratybu $(n=6)$. Tyrimo metu pagal krepšininkiu ŠSD buvo vykdomos 4 mažo ir vidutinio intensyvumo, 4 didelio intensyvumo, 4 didelio ir didžiausio intensyvumo pratybos.

Registruojant krepšininkių ŠSD rungtynių metu buvo stebimos Lietuvos moksleivių krepšinio lygos (MKL) rungtynès $(\mathrm{n}=6)$. Rungtynių metu buvo registruota žaideju (atskiru pozicijų) ŠSD prieš rungtynes, per atskirus rungtynių kèlinius, pasibaigus rungtynèms ir po rungtyniu praejjus 1 min (Klimontowicz, 1999).

Tiriamosios - Kauno m. krepšinio mokyklos 14-15 m. krepšininkès $(\mathrm{n}=18)$ : izžaidèjos $(n=6)$, vidurio puolejos $(n=5)$, krašto puolèjos $(\mathrm{n}=7)$. Krepšininkių ūgis $-173,7 \pm 6,11 \mathrm{~cm}$, kūno masè — 61,9 $\pm 6,69 \mathrm{~kg}$, žaidybinè patirtis $4,4 \pm 0,85 \mathrm{~m}$.

Statistinė analizė. Buvo skaičiuojami matuojamų rodiklių aritmetiniai vidurkiai $(\overline{\mathrm{x}})$ ir standartiniai nuokrypiai $(\mathrm{S} \overline{\mathrm{x}})$. Dèl nedidelių tiriamujų imčių taikyti neparametriniai kriterijai: priklausomoms imtims palyginti - Wilcoxon ženklų kriterijus. Reikšmingumo lygmuo - 0,05. Duomenų analizè atlikta naudojant SPSS for Windows programa.

\section{REZULTATAI}

Vienas objektyviausių, informatyviausių ir prieinamiausių žaidèjų reagavimo į pratybų ir rungtynių fizinius krūvius rodiklių yra širdies susitraukimu dažnis ( ̌̌SD) - kraujagyslèmis tekančio kairiojo širdies skilvelio išstumtas kraujo bangų skaičius per minutę (Brittenham, 1996; Janeira, 1998; Petridis et al., 2004; Balčiūnas, 2005 ir kt.).

1 paveiksle pavaizduota jaunujų krepšininkių vidutinio širdies susitraukimo dažnio rodikliai rungtynių metu. Ivairias žaidimo funkcijas atliekančių krepšininkių ŠSD per rungtynes kito skirtingai.

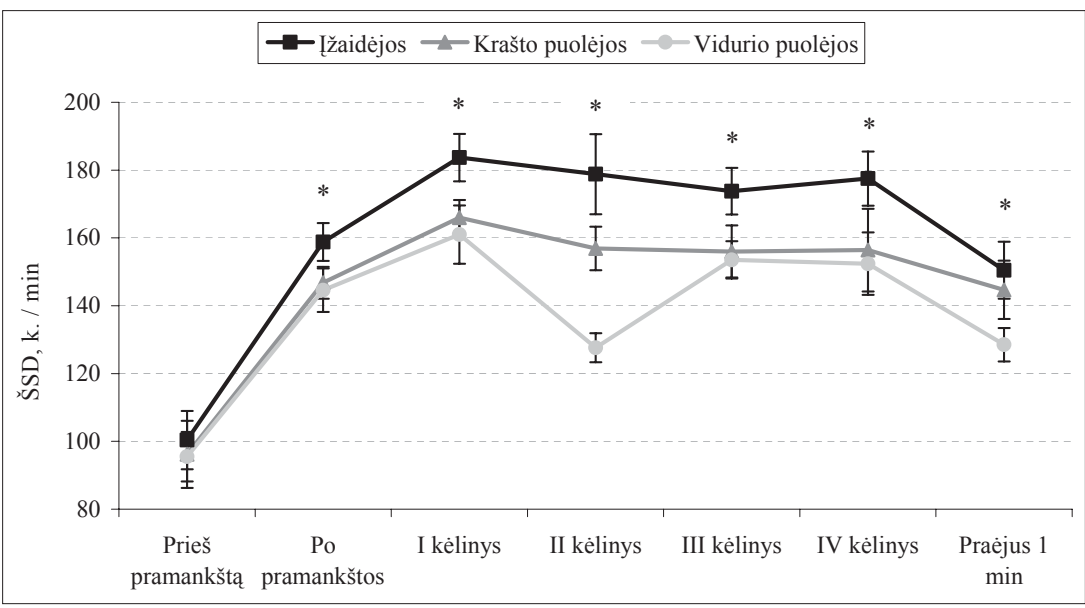

1 pav. Jaunųjų krepšininkių vidutinio ŠSD kaita rungtynių metu

Pastaba. * - p $<0,05$ - atskiru poziciju žaidejjų vidutinių ŠSD rodiklių skirtumas. 
2 pav. Jaunųjų krepšininkių vidutinio ŠSD kaita pratybų metu
Pastaba. * - p $<0,05$ - atskiru poziciju žaidèjų vidutinių ŠSD rodiklių skirtumas.

3 pav. Individualūs įžaidèjos ŠSD rodikliai per rungtynes ir pratybas
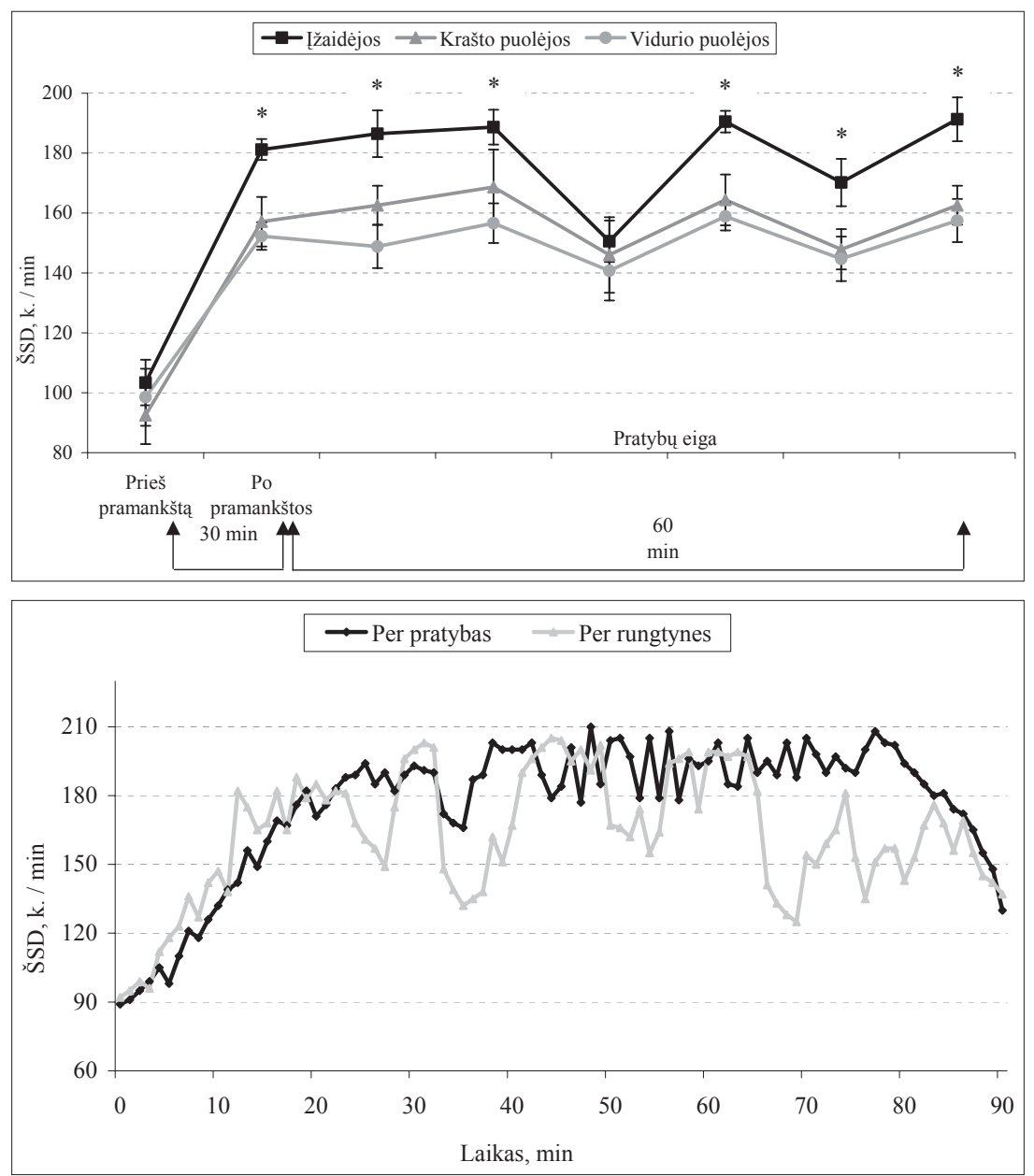

1-o kèlinio metu tirtų ižaidejų vidutinis ŠSD, lyginant su ŠSD po pramankštos, pakilo iki $183,7 \pm 3 \mathrm{k}$. / min, krašto puolejju — iki $166,0 \pm 3,2 \mathrm{k}$. / min, vidurio puoleju $-\mathrm{iki}$ $161,8 \pm 8,7 \mathrm{k} . / \mathrm{min}$.

Per 2 -ą kèlini pastebètas ižaidèjų $(178,3 \pm 11,8 \mathrm{k}$. / min) ir krašto puolèju $(156,9 \pm 6,4 \mathrm{k} . / \mathrm{min})$ vidutinio ŠSD sumažejjimas, lyginant su 1-o rungtynių kèlinio rodikliais. Smarkiai sumažejo vidurio puolejju vidutinio ŠSD rodiklis $(127,6 \pm 4,3 \mathrm{k} . / \mathrm{min})(\mathrm{p}<0,05)$.

3-iame kèlinyje vidurio puolèjų vidutinis ŠSD vẻl smarkiai pakilo $(153,5 \pm 5,5 \mathrm{k}$. / min; $\mathrm{p}<0,05)$, tačiau įžaidèjų ir krašto puolëjų sumažèjo atitinkamai iki $173,8 \pm 6,9$ ir $156,0 \pm 3,7 \mathrm{k}$. / min.

4-ame kèlinyje visu amplua žaideju vidutinis ŠSD kito nedaug. Izžaidejų didejo iki $177,5 \pm 10 \mathrm{k}$. / min, krašto puolèju - iki $156,4 \pm 12,2 \mathrm{k}$. / min, vidurio puolèjų sumažèjo iki $152,4 \pm 9,2 \mathrm{k} . / \min (\mathrm{p}>0,05)(1 \mathrm{pav}$.$) .$

Praejjus 1 min po rungtynių, smarkiai sumažejo ižaidejjų vidutinis ŠSD - iki 150,5 $\pm 8,4$ k. / min, vidurio puolejų $-108,5 \pm 1,9 \mathrm{k} . / \min (\mathrm{p}<0,05)$, krašto puolejju pakito nereikšmingai $144,7 \pm 8,6 \mathrm{k} . / \mathrm{min}(\mathrm{p}>0,05)$.
Didžiausias širdies susitraukimų dažnis per rungtynes buvo įžaidèjų. Statistiškai reikšmingas vidutinio ŠSD rodiklio skirtumas tarp ižaidejų ir krašto puolèjų, lyginant rodiklius po pramankštos, I, II, III kèlinio $(\mathrm{p}<0,05)$. Ižaidèjų ir vidurio puolèjų vidutinio ŠSD rodiklio skirtumas nustatytas po pramankštos, per visus keturis kèlinius ir po rungtynių praejus 1 min $(\mathrm{p}<0,05)$. Didelis krašto puolejų ir vidurio puolèjų šio rodiklio skirtumas nustatytas 2-o kèlinio metu ir po rungtyniu praejjus $1 \mathrm{~min}(\mathrm{p}<0,05)$.

Ivairių amplua žaidejų vidutinis ŠSD rodiklis kito panašiai kaip ir rungtynių metu (ižaidèjų 184,6 k. / min, krašto puolèju - 157,4 k. / min), vidurio puolejju $(142,1 \mathrm{k}$. / min) - pratybų metu (2 pav.).

Ižaidèju vidutinis ŠSD prieš pramankštą buvo 103,4 \pm 1,6 k. / min, krašto puolèjų $-92,5 \pm 9,6 \mathrm{k}$. / min, vidurio puolèju — 98,5 $\pm 9,5 \mathrm{k} . / \mathrm{min}$.

Po pramankštos krašto ir vidurio puolèju vidutinis ŠSD padidejo atitinkamai iki $157,1 \pm 8,3$ ir $152,3 \pm 4,6 \mathrm{k}$. / min, izžaidejju $181,2 \pm 3,5 \mathrm{k} . / \mathrm{min}$.

Po pramankštos praejus 15 min pratybų laiko (tai atitinka rungtynių pirmą kèlini), įžaidèju 

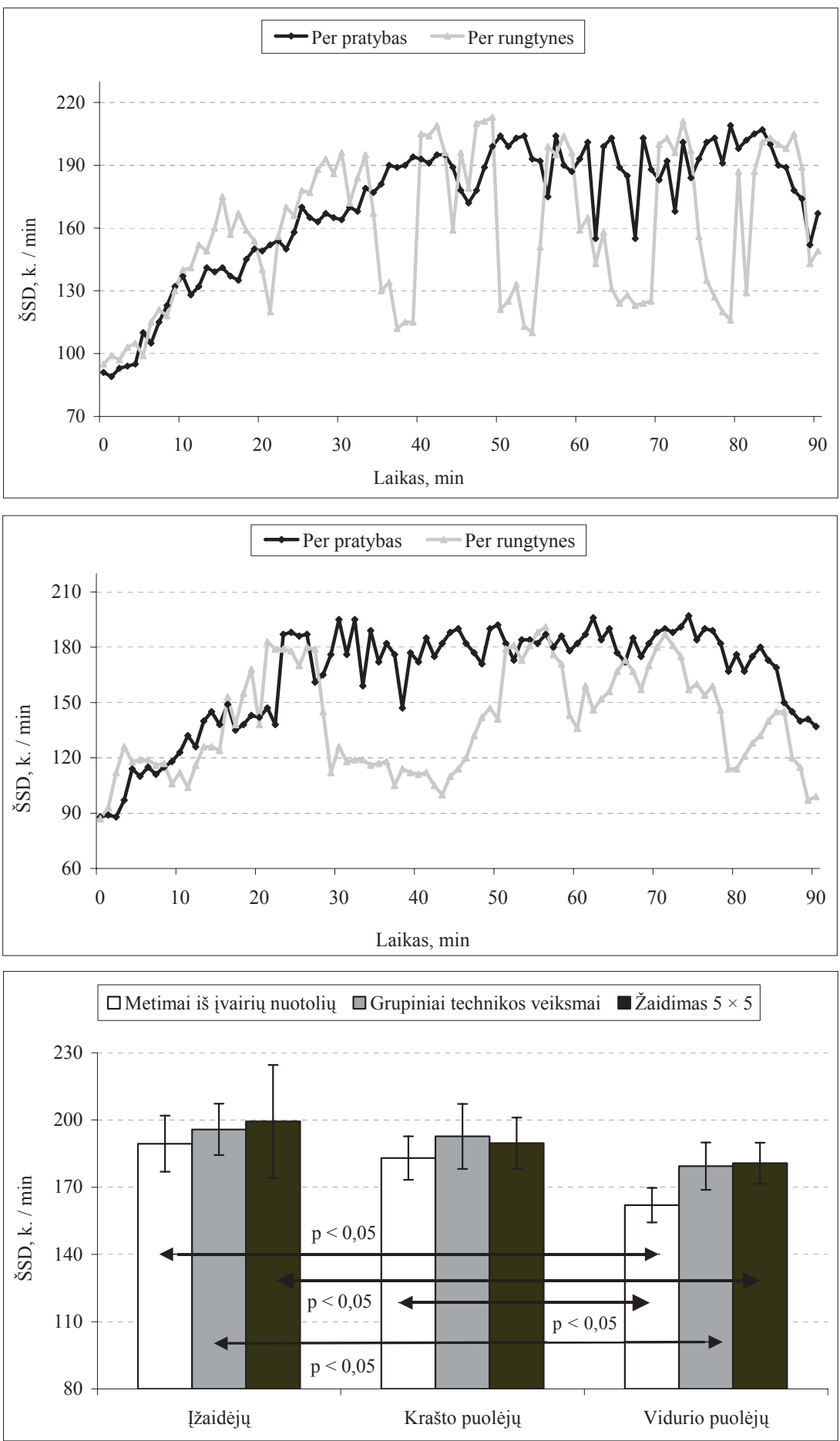

4 pav. Individualūs krašto puolèjos ŠSD rodikliai per rungtynes ir pratybas
5 pav. Individualūs vidurio puolèjos ŠSD rodikliai per rungtynes ir pratybas
6 pav. Jaunųjų krepšininkių ŠSD reakcija ị specifinius fizinius krūvius
Pastaba. $\mathrm{p}<0,05$, lyginat atskiru poziciju žaidèjų vidutinių ŠSD rodiklių skirtumus. vidutinis ŠSD buvo $186,5 \pm 2,1$ k. / min, krašto puolèju $-162,6 \pm 6,5 \mathrm{k}$. / min, vidurio puolèju $148,8 \pm 7,2 \mathrm{k} . / \mathrm{min}$.

Intensyviausiai fizinius krūvius atliko įžaidèjos, kurių vidutinis ŠSD po 30 min pratybu (atitinka rungtynių antrą kèlini) buvo 188,7 $\pm 5,8 \mathrm{k}$. / min, krašto puolejju - 168,7 $\pm 12,5 \mathrm{k}$. / min. Vidurio puolèjų vidutinis S̆SD rodiklis, praejjus $30 \mathrm{~min}$ pratybų laiko, buvo mažiausias - 156,6 $\pm 6,6 \mathrm{k}$. / min (2 pav.).

Po pratybų, atitikusių rungtynių intensyvumą (rungtynių 2 kèlinius), praejjus 30 min buvo atlieka- mi mažo intensyvumo 5 min trukmès fiziniai pratimai (metimai iš įvairių nuotolių, kamuolio perdavimai vietoje ir pan.), po kurių vidutinis krepšininkiu ŠSD nukrito: į̌aidèju - 150,6 \pm 6,9 k. / min; krašto puolèju $-146,0 \pm 12,6 \mathrm{k}$. / min; vidurio puolèjų - 140,7 $\pm 9,9 \mathrm{k}$. / min.

Pratybų pabaigoje ižaidèjų vidutinis ŠSD rodiklis pasiekè aukščiausią ribą - 191,3 \pm 7,3 k. / min, krašto puolèju $-162,6 \pm 6,5 \mathrm{k}$. $/ \mathrm{min}$, vidurio puolèju $-157,5 \pm 7,2 \mathrm{k}$. / min.

Visų pratybų metų buvo nustatytas įžaidèjų, krašto ir vidurio puolejjų didelis vidutinis širdies 
susitraukimų dažnio skirtumas $(p<0,05)$, išskyrus tą pratybų laikotarpi, kai žaidèjos atliko mažo intensyvumo fizinius pratimus (praejus 45 min nuo pratybu pradžios) $(p>0,05)(2$ pav.).

Iš pateiktų individualiu įžaidèjos ŠSD rodiklių per rungtynes ir pratybas (3 pav.) nustatyta, kad pramankštos metu (10-20 minučiu) ŠSD pamažu didèjo. 1-ame rungtynių kèlinyje pastebimas ŠSD svyravimas. Tuo tarpu pratybų metu po pramankštos ižaidèjos ŠSD kito nedaug.

2-o kèlinio metu ižaidejjos ŠSD kilo nuo 138 iki $200 \mathrm{k} . /$ min. 3-iame kèlinyje ŠSD pastovus, tik likus keletui minučių iki kẻlinio pabaigos ŠSD staiga sumažèjo nuo 199 iki $125 \mathrm{k}$. / min.

Prasidèjus 4-am kèliniui, ižaidèjos ŠSD buvo $180 \mathrm{k}$. / min ir labai svyrvo. Po rungtynių pastebimas tolygus organizmo atsigavimas. Pratybu pabaigoje (80 - 90 min) ŠSD mažèjo taip pat lètai nuo 194 iki 130 k. / min. Rungtynių metu įžaidèju ŠSD kito nuo 194 iki 148 k. / min (3 pav.).

Iš pateiktų individualių krašto puolèjos ŠSD rodikliu per rungtynes ir pratybas (4 pav.) nustatyta, kad šios pozicijos žaidejjos ŠSD pramankštos metu prieš rungtynes $(10-20 \mathrm{~min})$ pakilo labiau, nei per iprastas pratybas šiuo laikotarpiu. Vadinasi, krašto puolèjos fizinius krūvius intensyviau atlieka per rungtynes nei per pratybas.

1-ame kèlinyje krašto puolèjos ŠSD pakilo iki 196 k. / min, o pasibaigus kèliniui krito iki $112 \mathrm{k}$. / min. 2-ame kèlinyje šis rodiklis buvo panašus. ŠSD kèlinio pradžioje pakilo, pabaigoje staiga sumažejo. Analogiški 3-io ir 4-o kèlinio rodikliai - ŠSD smarkiai svyruoja. Praejjus pusei pratybu laiko, krašto puolèja gebejjo išlaikyti ŠSD gana pastovų, tačiau praejjus daugiau negu pusei pratybu ŠSD pradeda smarkiai svyruoti (195 $155 \mathrm{k}$. / min amplitude). Tokius ŠSD svyravimus pratybu metu galejo lemti atsiradęs nuovargis.

Individualūs vidurio puolèjos ŠSD rodikliai per iprastas pratybas po pramankštos svyravo 145 $187 \mathrm{k}$. / min amplitude (5 pav.).

Šie svyravimai buvo didžiausi $30-40$ pratybų minutę. Rungtynių metu, kaip ir per pratybas, pramankštos laikotarpiu vidurio puolejos ŠSD pamažu kilo virš $150 \mathrm{k}$. / min ribos.

1-o kèlinio pabaigoje vidurio puolejos ŠSD sumažėjo iki 112 k. / min. ŠSD (120105 k. / min) rodo, kad per 2-ą rungtynių kèlini aikštelèje žaide žemo ūgio žaidèjos, o vidurio puolèja ilsėjosi.

6 paveiksle pavaizduota jaunujų krepšininkiu ŠSD reakcija i specifinius fizinius krūvius, kurie buvo suskirstyti $\mathfrak{i}$ tris grupes: metimai iš iqvairių nuotolių, grupiniai technikos veiksmai ir žaidimas $5 \times 5$.

Atliekant metimus iš įvairių nuotolių, didžiausias ŠSD rodiklis buvo ižaidèju $-189,4 \pm 12,5 \mathrm{k}$. / min, krašto puolèjų $-183,0 \pm 11,5 \mathrm{k}$. / min, vidurio puolejju $-162 \pm 25,2 \mathrm{k}$. / min.

Atliekant grupinius technikos veiksmus, ŠSD rodikliai taip pat buvo didžiausi ižaideju (195,8 \pm 9,7 k. / min), šiek tiek mažesni krašto puolèjų (192,7 $\pm 14,5$ k. / min), mažiausi - vidurio puolejuc $(179,4 \pm 11,4 \mathrm{k}$. / $\mathrm{min})$.

Analogiškas atvejis buvo ir žaidimo $5 \times 5$ metu. Rungtyniaujant tarpusavyje izžaideju ŠSD buvo 199,4 \pm 7,7 k. / min, krašto puolèju $-189,7 \pm 10,6 \mathrm{k}$. / min, vidurio puoleju $180,7 \pm 9,2 \mathrm{k} . /$ min (6 pav.).

Ižaidèjų, krašto ir vidurio puolëjų ŠSD panašūs atliekant grupinius technikos veiksmus ir žaidžiant $5 \times 5$. Nedaug mažesnis širdies susitraukimų dažnis buvo ižaidejjoms ir krašto puolejjoms metant iš iqvairiu nuotoliu ( $p>0,05)$, o vidurio puolèju — daug mažesnis metant metimus nei atliekant grupinius technikos veiksmus ir rungtyniaujant tarpusavyje $(\mathrm{p}<0,05)$.

Atliekant grupinius technikos veiksmus, žaidimo $5 \times 5$ ir metimu iš įvairių nuotoliu metu ŠSD rodikliai buvo kur kas didesni ižaidèjų ir krašto puolejjų nei vidurio puolejjų $(\mathrm{p}<0,05)$.

\section{REZULTATŲ APTARIMAS}

W. Klimontowicz (1999) pagal ŠSD rodiklius išskyrè tokias fizinio krūvio intensyvumo ribas:

- didžiausio (ŠSD - 181-230 k. / min);

- beveik didžiausio (ŠSD - 170190 k. / min);

- didelio ( ŠSD - 161-170 k. / min);

- vidutinio (ŠSD - 140-160 k. / min).

Remiantis W. Klimontowicz pateiktais rodikliais galima teigti, kad mūsų tirtų krepšininkių vyraujančio krūvio intensyvumas per pratybas ir per rungtynes buvo beveik didžiausias: ižaideju per pratybas - 176,8 k. / min, per rungtynes 180,8 k. / min; krašto puolejų — atitinkamai $178,4 \mathrm{k} . / \mathrm{min}, 186,2 \mathrm{k} . / \mathrm{min}$; vidurio puoleju atitinkamai 182,6 k. / min, 180,6 k. / min.

Tirtų krepšininkių vyraujantis fizinis krūvis (ŠSD) per rungtynes $(180,8 \mathrm{k}$. / min) atitinka kitu autoriu pateiktus orientacinius rodiklius. Tokio intensyvumo fizinis krūvis per rungtynes sudaro $40 \%$ viso rungtynių laiko (Apostalidis et al., 2001; Papodopoulos et al., 2002). 
Rungtynių metu vidutinio ŠSD rodikliu skirtumas tarp izžaidejjų ir krašto puolèjų buvo reikšmingas $(\mathrm{p}<0,05)$. Taip pat reikšmingas ¡žaidejų ir vidurio puolèju rodiklių skirtumas $(\mathrm{p}<0,05)$, tačiau tarp krašto puolejju ir vidurio puolèjų reikšmingo rodiklių skirtumo nenustatyta $(\mathrm{p}>0,05)$.

Tirtų žaidejų ŠSD raidos tendencijos rengiantis rungtynėms (po pramankštos) ir žaidžiant iš esmès atitinko kitų autorių pateiktus rodiklius: ŠSD prieš pramankštą — $\sim 60 \mathrm{k}$. / min, po pramankštos $\sim 160 \mathrm{k} . / \mathrm{min}$, po pirmo kèlinio $-\sim 180 \mathrm{k}$. / min (Apostalidis et al., 2002).

ŠSD kaita po rungtynių rodo skirtingą tirtu krepšininkių specialuji fizini parengtumą. Po rungtynių praejjus 5 min, ižaidèjų ŠSD sumažèjo $15 \%$, krašto puolèju $-8 \%$, vidurio puolèju $-30 \%$.

W. Klimontowicz (2002) duomenimis, jei po 1 poilsio minutès ŠSD buvo $\sim 200 \mathrm{k}$. / min, tai jis sumažèjo $\sim 30 \%$.

S. Stonkus (2003) teigia, kad per baudos metimu serijomis po 10 pratybas ŠSD siekia 125 $130 \mathrm{k}$. / min, žaidimo $2 \times 2,3 \times 3$ prie vieno krepšio metu $-180-190$ k. / min. Mūsų tirtu krepšininkiu ŠSD žaidimo $2 \times 2,3 \times 3$ prie vieno krepšio metu siekè 180-190 k. / min ribas.

Pratybu ir rungtynių fizinio krūvio intensyvumo (ŠSD) rodikliu analizè, palyginimas su kitu tyrejjų duomenimis patvirtino teorinę prielaidą: žaidèjų organizmo prisitaikymas prie įvairių fizinių krūvių, žaidimo situacijų, reagavimas i jas yra sudetingas vyksmas, gana skirtingas net tarp to paties amžiaus žaidèjų. Taigi krepšininkių sportinis rengimas nuo pat ankstyvo amžiaus turi vykti tikslingai ir kryptingai (Bompa, 1999; Buceta, 2000; Di Lorenzo, Saibene, 1996), atsižvelgiant i organizmo galimybes prisitaikyti prie izvairaus fizinio krūvio.

\section{IŠVADOS}

1. Tirtų jaunujų krepšininkių (ižaidèjų, krašto ir vidurio puolejų) fizinių krūvių intensyvumas per pratybas ir rungtynes atitiko beveik didžiausio intensyvumo krūvio ribas.

2. Visų amplua žaidejjų fizinio krūvio intensyvumas per rungtynes ir pratybas sąlygiškai adekvatus: tai patvirtina statistiškai nereikšmingas vyraujančių krūvių intensyvumo rodiklių (ŠSD) per pratybas ir rungtynes skirtumas $(\mathrm{p}>0,05)$.

3. Skirtingų pozicijų žaidejjų veikla lemia skirtingą fiziologini atsaką i i vairaus intensyvumo fizinius krūvius: ižzaidejų ŠSD, atliekant fizinius krūvius, yra kur kas didesnis, lyginant su vidurio ir krašto puolèjų rodikliais $(\mathrm{p}<0,05)$. Vidurio puolèjos į fizini krūvị reaguoja silpniausiai.

\section{LITERATŪRA}

Apostolidis, N., Anastasiadis, M., Geladas, N., Nassis, G. (2001). Physiological Profile and Technical Characteristics of Young Elite Basketball Players: $6^{\text {th }}$ Annual Congress of the European College of Sport Science. Cologne, 24-28 July (p. 1296).

Avakumovič, A. (2000). Training Sessions with 13-14 Year-Old Players. In Basketballfor Young Players. Madrid: FIBA. P. 207-263.

Balčiūnas, M. (2005). Optimizuotu fiziniu krūviu taikymo veiksmingumas rengiant jaunuosius krepšininkus: daktaro disertacija. Klaipèdos universitetas.

Bompa, T. O. (1999). Periodization: Theory and Methodology of Training. $4^{\text {th }}$ Edition. USA: Human Kinetics.

Brittenham, G. (1996). Complete Conditioning for Basketball. USA: Human Kinetics.

Buceta, J. M. (2000). Planing Basketball Activities. Basketball for Young Players. Madrid: FIBA. P. 38-82.

Crespo, M., Miley, D. (1998). Advanced Coaches Manual. Canada: ITF.

Janeira, A. M., Maia, J. (1998). Game intensity in basketball. An interactionist view linking time - motion analysis, lactate concentration and heart rate. Coaching \& Sport Science, 3 (2), 26-30.

Keen, G. (1995). The presentation of overtraining: A time to re-examine training philosophy? Coaching Focus, 28, $12-13$.

Klimontowicz, W. (1999). Koszykowka. Warszawa: Centralny osrodek sportu.

Di Lorenzo, R., Saibene, G. (1996). Teaching basketball. Roma: World Association of Basketball Coaches.

Milanovič, D., Heimer, S., Jukič, J. (2002). Training Load Programming in Sport: $7^{\text {th }}$ Annual Congress of the European College of Sport Science. Proceding, 24-26 July, Athens.

Papodopoulos, P., Schmidt, G., Stafilidis, S., Baum, K. (2002). The Characteristics of the Playing and Break Times of a Basketball Game: $7^{\text {th }}$ Annual Congress of the European College of Sport Science. Athens, 24-25 July.

Petridis, L., Horvath, P., Kneffel, Z., Pavlik, G. (2004). Effects of different sport events on cardiac adaptation in young age: $10^{\text {th }}$ Annual Congress of the European College of Sport Science. Athens, 24-28 July.

Stonkus, S. (2003). Krepšinis. Istorija. Teorija. Didaktika. Kaunas.

Созанский, Х., Полищук, Д. (2003). Тренировочные нагрузки как фактор управления развития спортивной карьеры: Материаль международного конгресса «Спортивный Олимпийский спорт и спорт для всех». Май 24-27, Москва. 


\title{
ANALYSIS OF ADEQUACY OF PHYSICAL LOAD INTENSITY OF YOUNG FEMALE BASKETBALL PLAYERS DURING TRAINING SESSIONS AND MATCHES
}

\author{
Rasa Kreivytė, Šarūnė Valinskaitè \\ Lithuanian Academy of Physical Education, Kaunas, Lithuania
}

\begin{abstract}
Even in the 1980s the heart rate was considered to be an objective and informative index of players' response to physical loads and their physical fitness. The course of a basketball match or a training session is not uniform, the heart rate changes together with the intensity of the game, making shots, during a minute break, etc. Thus the mean index of the changing heart rate when the intensity of the game changes creates undulate sets of data.

Aiming to obtain optimal changes in training we must apply the most appropriate physical loads for training sessions and matches which matched the adaptive abilities of basketball players, the aims and objectives of their physical training.

The aim of the study was to evaluate the intensity of physical load and its adequacy during the training sessions and matches.

Research objectives were as follows: 1) to establish the intensity of physical loads during the training sessions and matches; 2) to evaluate the relative degree of adequacy of physical loads in training sessions and matches; 3 ) to reveal the peculiarities of $14-15$ year-old basketball players' response to specific physical loads.

Research results: We studied 18 female basketball players. During the training sessions the dominant index of physical load intensity (HR) of guards was $186.5 \pm 7.8 \mathrm{bt} / \mathrm{min}$, forwards $-162.6 \pm 6.5 \mathrm{bt} / \mathrm{min}$, and centers $-156.6 \pm 6.6 \mathrm{bt} / \mathrm{min}$.

During the matches the dominant index of physical load intensity (HR) of guards was $180.8 \pm 7.85 \mathrm{bt} / \mathrm{min}$, forwards $-156.2 \pm 7.4 \mathrm{bt} / \mathrm{min}$, and centers $-150.6 \pm 11.72 \mathrm{bt} / \mathrm{min}$.

During the matches the guards demonstrated the greatest heart rate in the first quarter $(183.7 \pm 3 \mathrm{bt} / \mathrm{min})$, forwards — in the second quarter $(156.9 \pm 6.4 \mathrm{bt} / \mathrm{min})$ and centers — in the third quarter $(153.5 \pm 5.5 \mathrm{bt} / \mathrm{min})$.

Physical load intensity of the studied female basketball players (guards, forwards and centers) was within the limits of almost maximal intensity of physical loads. The bodies of young female basketball players performing different functions in the game reacted differently to physical loads of various intensities: the heart rates of guards during physical loads were higher than those of forwards and centers. Centers reacted to physical loads least of all.
\end{abstract}

Keywords: physical loads of young basketball players, load intensity, heart rate.

Gauta 2009 m. rugsèjo 26 d.

Received on September 26, 2009

Lietuvos kūno kultūros akademija

(Lithuanian Academy of Physical Education)

Sporto g. 6, LT-44221 Kaunas

Lietuva (Lithuania)

Tel +370 37302653

E-mail kreivyte@centras.lt 